\title{
Stable bromine isotopic composition of methyl bromide released from plant matter
}

Axel Horst $^{\mathrm{a}, \mathrm{b}, 1}$, Henry Holmstrand ${ }^{\mathrm{a}, \mathrm{b}^{*}}$, Per Andersson ${ }^{\mathrm{c}}$, Brett F. Thornton ${ }^{\mathrm{b}, \mathrm{d}}$, Asher Wishkerman $^{\mathrm{e}, 2}$, Frank Keppler ${ }^{\mathrm{e}}$, Örjan Gustafsson ${ }^{\mathrm{a}, \mathrm{b}}$

${ }^{a}$ Department of Applied Environmental Science, Stockholm University, Stockholm, Sweden ${ }^{\mathrm{b} B o l i n}$ Centre for Climate Research, Stockholm University, Stockholm, Sweden

'Laboratory for Isotope Geology, Swedish Museum of Natural History, Stockholm, Sweden

${ }^{\mathrm{d} D e p a r t m e n t ~ o f ~ G e o l o g i c a l ~ S c i e n c e s, ~ S t o c k h o l m ~ U n i v e r s i t y, ~ S t o c k h o l m, ~ S w e d e n ~}$

${ }^{\mathrm{e} M a x-P l a n c k-I n s t i t u t e}$ for Chemistry, Hahn-Meitner-Weg 1, Mainz, Germany

*Corresponding Author:

Henry Holmstrand

Stockholm University

Department of Applied Environmental Science

Bolin Centre for Climate Research

10691 Stockholm, Sweden

henry.holmstrand@itm.su.se

tel. +46 (0)8 6747229

1 present address: Department of Earth Sciences, University of Toronto, M5S 3B1, Canada, horst(at)es.utoronto.ca

${ }^{2}$ present address: IRTA-SCR, Carretera Poble Nou Km 5.5, E-43540 Sant Carles de la Ràpita, Catalonia, Spain 


\begin{abstract}
Methyl bromide $\left(\mathrm{CH}_{3} \mathrm{Br}\right)$ emitted from plants constitutes a natural source of bromine to the atmosphere, and is a component in the currently unbalanced global $\mathrm{CH}_{3} \mathrm{Br}$ budget. In the stratosphere, $\mathrm{CH}_{3} \mathrm{Br}$ contributes to ozone loss processes. Studies of stable isotope composition may reduce uncertainties in the atmospheric $\mathrm{CH}_{3} \mathrm{Br}$ budget, but require well-constrained isotope fingerprints of the source end members. Here we report the first measurements of stable bromine isotopes $\left(\delta^{81} \mathrm{Br}\right)$ in $\mathrm{CH}_{3} \mathrm{Br}$ from abiotic plant emissions. Incubations of both $\mathrm{KBr}$-fortified pectin, a ubiquitous cell-stabilizing macromolecule, and of a natural halophyte (Salicornia fruticosa), yielded an enrichment factor $(\varepsilon)$ of $-2.00 \pm 0.23 \%$ o $(1 \sigma, \mathrm{n}=8)$ for pectin and $-1.82 \pm 0.02 \%$ o $(1 \sigma, \mathrm{n}=4)$ for Salicornia (the relative amount of ${ }^{81} \mathrm{Br}$ decreased in $\mathrm{CH}_{3} \mathrm{Br}$ compared to the substrate salt). For short incubations, and up to $10 \%$ consumption of the salt substrate, this isotope effect was similar for temperatures from 30 up to $300^{\circ} \mathrm{C}$. For longer incubations of up to 100 hours at $180^{\circ} \mathrm{C}$ the $\delta^{81} \mathrm{Br}$ values increased from $-2 \%$ to $0 \%$ for pectin and to $-1 \%$ for Salicornia. These $\delta^{81} \mathrm{Br}$ source signatures of $\mathrm{CH}_{3} \mathrm{Br}$ formation from plant matter combine with similar data for carbon isotopes to facilitate multidimensional isotope diagnostics of the $\mathrm{CH}_{3} \mathrm{Br}$ budget.
\end{abstract}

Keywords: 81Br/79Br; enrichment factor, abiotic formation, pectin, halophyte 


\section{Introduction}

Methyl bromide $\left(\mathrm{CH}_{3} \mathrm{Br}\right)$ is the most important source of $\mathrm{Br}$ radicals in the stratosphere. It accounts for $15 \%$ of the ozone depletion potential caused by halogen species (Butler, 2000). Consequently, the use of $\mathrm{CH}_{3} \mathrm{Br}$ as a fumigant is scheduled to be phased out by 2015 under amendments to the Montreal Protocol (Montzka et al., 2011). However, methyl bromide is also released naturally from oceans (King et al, 2002), biomass burning (Andreae and Merlet, 2001), salt marshes (Rhew et al., 2000), wetlands (Varner et al., 1999), fungi (Harper, 1985), and several plant species (Gan et al., 1998, Wishkerman et al., 2008). The main sinks are believed to be uptake by oceans (Butler et al., 2007) and soils (Shorter et al., 1995) as well as reaction with $\mathrm{OH}$ radicals in the atmosphere (Saltzman et al., 2004). Although most of these source and sink processes appear to be relatively well investigated, albeit facing upscaling challenges common to most bottom-up approaches, the global budget shows an imbalance of $32 \mathrm{Gg} / \mathrm{a}$ corresponding to ca. $25 \%$ of the known annual emissions (Yvon-Lewis et al., 2009). Hence, sources are either underestimated and/or sinks are overestimated.

Emissions from plants may add considerably to the $\mathrm{CH}_{3} \mathrm{Br}$ atmospheric budget. Warwick et al. (2006) ran an inverse model of currently observed mixing ratios in the atmosphere and identified a terrestrial source from tropical vegetation. Biotic and abiotic reaction mechanisms have been described. For the biotic reaction pathway, living plants are producing methyl halides in their cells as a result of enzymatic reactions (Saito and Yokouchi 2006 and references therein). Blei et al. (2010) performed flux measurements on branches and leaves in a southeast Asian tropical rainforest and found emissions up to $3 \mathrm{ng} \cdot \mathrm{h}^{-1} \cdot \mathrm{gdw}^{-1} \mathrm{CH}_{3} \mathrm{Br}$ (gram dry weight). Large scale airborne measurements over the South American tropical rainforest showed small net fluxes because of local sinks such as photolysis and soil uptake (Gebhardt et al., 2008). Both studies demonstrate that vegetation in the tropics might be an important source of methyl bromide to the atmosphere.

Apart from biotic production of living plants, an abiotic reaction pathway has been described for $\mathrm{CH}_{3} \mathrm{Br}$ following a nucleophilic substitution reaction $\left(\mathrm{S}_{\mathrm{N}} 2\right)$ (Hamilton 
et al., 2003; Keppler et al., 2004). The methoxy groups of pectin and lignin, both abundant cell-stabilizing macromolecules, react with halide ions dissolved in the tissue water of the plants (Khan et al., 2001) (Fig. 1a) or present as hydrogen bonded ions on the pectin molecule (Fig 1 b). Up to $52 \%$ of the halide ions may be $\mathrm{H}$-bonded to functional groups of the organic molecules (Myneni, 2002). These halide ions form acids, either with protons from the unesterified carboxylic acid group of the pectin molecule (McRoberts, 2011) (Fig 1a) or from the surrounding water (Fig 1b). The acids can cleave the methoxy group from the pectin molecule in a nucleophilic substitution reaction with a methyl halide as one product. The same reaction pathway has been suggested for bromide salts (Hamilton et al., 2003).

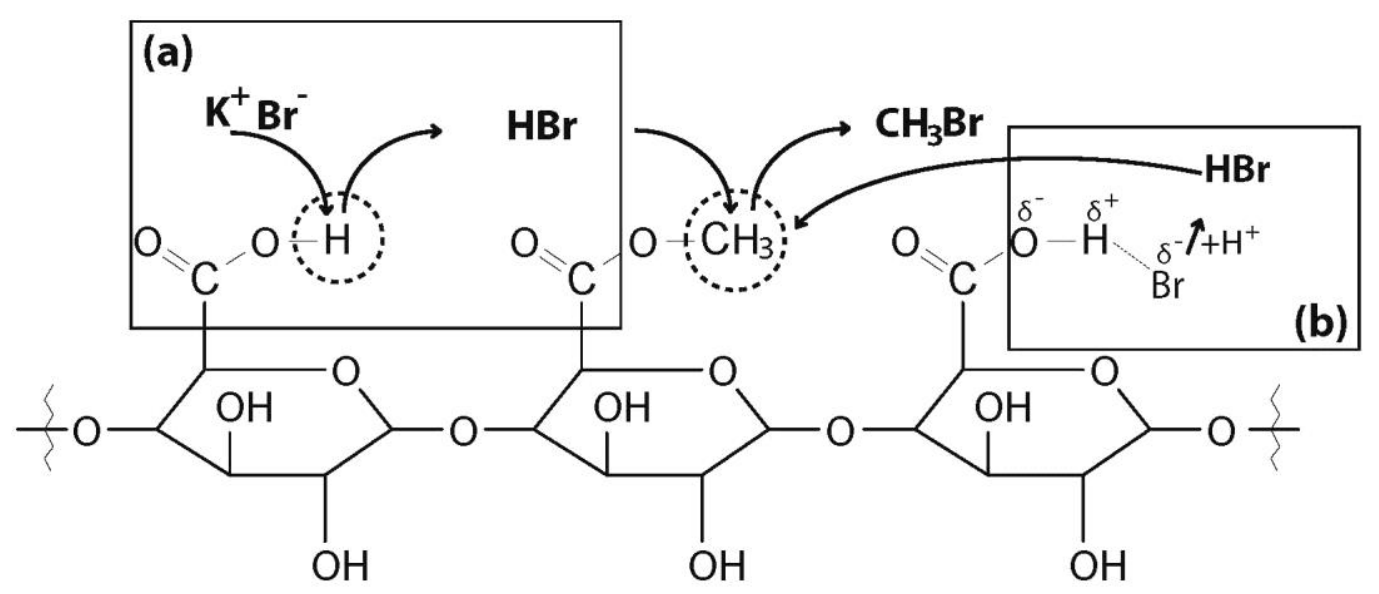

Fig. 1. Suggested chemical reaction pathway for the formation of methyl halides from pectin: (a) $\mathrm{CH}_{3} \mathrm{Br}$ formation from pectin and salt modified after McRoberts (2011) and (b) from H-bonded bromide.

This abiotic reaction pathway was suggested to be an important source to the atmospheric methyl halide budget (Keppler et al., 2005; Wishkerman et al., 2008). It accounts for both low temperature emissions from dead and senescent plant material (Derendorp et al., 2012) and, together with the lignin methoxy groups, for biomass burning (Andreae and Merlet, 2001; van der Werf et al., 2006). For methyl chloride $\sim 20-25 \%$ of the estimated total budget might come from biomass burning and a similar amount from senescent plants and plant litter (Keppler et al., 2005; Saito and Yokouchi, 2008). For methyl bromide approximately $10 \%$ of the 
atmospheric budget might originate from biomass burning (Yvon-Lewis et al., 2009). While vegetation-based emissions of $\mathrm{CH}_{3} \mathrm{Br}$ have the potential to reduce the estimated imbalance between sources and sinks in the atmospheric budget, lowtemperature formation from senescent and dead plant matter has not yet been included in the global budget because quantification is difficult.

The current estimates for plant emissions of $\mathrm{CH}_{3} \mathrm{Br}$ are based largely on small-scale concentration or flux measurements (Gebhardt et al., 2008; Blei and Heal, 2011) and are not well constrained. Hence stable isotope techniques are starting to be explored to improve the source apportionment of methyl halides. Carbon-13 analysis on atmospheric samples was first shown for $\mathrm{CH}_{3} \mathrm{Cl}$ by Rudolph et al. (1997) and since then it was applied in various studies to characterize source (Thompson et al., 2002; Keppler et al., 2004; Saito and Yokouchi, 2008) and sink signatures (Gola et al., 2005; Sellevag et al., 2006). A first $\delta^{13} \mathrm{C}$ isotope based budget estimate was accomplished by Keppler et al. (2005). Recently, the hydrogen isotopic composition of $\mathrm{CH}_{3} \mathrm{Cl}$ released from halophyte plant species was investigated (Greule et al., 2012).

Isotope studies on $\mathrm{CH}_{3} \mathrm{Br}$ are much scarcer mainly because of its low atmospheric mixing ratio and small emission rates from its sources. Signatures of $\delta^{13} \mathrm{C}$ have been determined for fumigation products (McCauley et al., 1999), salt marshes (Bill et al., 2002) and tropospheric air (Bill et al., 2004; Bahlmann et al., 2011). However, $\delta^{13} \mathrm{C}$ values of salt marsh emissions (-43\%o VPDB) and the troposphere $(-42.3 .1 \%$ o VPDB) are difficult to distinguish. Industrial $\mathrm{CH}_{3} \mathrm{Br}$ products have more negative $\delta^{13} \mathrm{C}$ values (-54\%o VPDB).

Bromine has two stable isotopes ${ }^{79} \mathrm{Br}(51.69 \%)$ and ${ }^{81} \mathrm{Br}(49.31 \%)$ with an average ${ }^{81} \mathrm{Br} /{ }^{79} \mathrm{Br}$ ratio of 0.954 (e.g. Wieser et al., 2013). The small mass difference of $2.5 \%$ causes only minor but measureable isotope fractionation. Two previous studies reported $\delta^{81} \mathrm{Br}$ values of $-0.80 \%$ to $+3.35 \%$ SMOB (Standard Mean Ocean Bromide) for deep groundwaters of the Siberian Platform (Shouakar-Stash et al., 2007 ) and -4.3 to $-0.4 \%$ SMOB for industrially produced brominated organic 
compounds (Carrizo et al., 2011) thus giving a $\delta^{81} \mathrm{Br}$ range of ca. $8 \%$. Two recent articles reported isotope enrichment factors $(\varepsilon)$ of $-0.2 \%$ to $-0.76 \%$ for microbial debromination of brominated phenols (Bernstein et al., 2013) and $-0.5 \%$ to $-2.7 \%$ observed for Grignard reagent formation (Szatkowski et al., 2013) showing the potential to identify certain processes and reactions by using $\mathrm{Br}$ isotope analysis.

A method to measure bromine isotopes in $\mathrm{CH}_{3} \mathrm{Br}$ was recently established (Horst et al., 2011) and the first $\delta^{81} \mathrm{Br}$ isotope values for ambient tropospheric $\mathrm{CH}_{3} \mathrm{Br}$ are in the range of -0.47 to $+1.75 \%$ SMOB (Horst et al., 2013). Despite the small $\delta^{81} \mathrm{Br}$ range, the high-precision values could be used to identify a degradation trend and to start considering the influence of potential sources on the tropospheric $\delta^{81} \mathrm{Br}$ composition of $\mathrm{CH}_{3} \mathrm{Br}$.

Here we report the first measurements of bromine isotopes in $\mathrm{CH}_{3} \mathrm{Br}$ derived from incubations with thermally-treated plant matter to explore its feasibility to aid in addressing the abiotic plant source. We suggest a potential $\delta^{81} \mathrm{Br}$ source range and investigate the fractionation process caused by this abiotic production pathway of $\mathrm{CH}_{3} \mathrm{Br}$ in senescent plants and dry plant litter.

\section{Method}

\subsection{Plant sample and pectin}

For our experiments we used $\mathrm{KBr}$-fortified apple pectin (Sigma Aldrich) and dried leaf samples of the halophyte Salicornia fruticosa collected in tidal areas on Sardinia, Italy. The fortified pectin was prepared in the following way: Potassium bromide (KBr, Sigma Aldrich) solution (1.5 mg KBr, $100 \mathrm{~mL}$ ) was placed in a beaker and heated to $50^{\circ} \mathrm{C}$. Pectin $(10 \mathrm{~g})$ was slowly added while stirring. Then the formed gel was mixed ( 2 min) with an Ultra-Turrax ${ }^{\circledR}$ blender and transferred onto an aluminum foil tray and cooled. After freezing, the pectin was lyophilized and ground. Salicornia leaves, in total ca. $250 \mathrm{gdw}$ from many different plants, were dried at room temperature and ground. Analysis of methoxy and (blank) salt concentrations was carried out prior to the incubation experiments. To determine 
the methoxy content the functional groups of esters and ethers of pectin were reacted with hydriodic acid to form alkyl iodides which were analyzed by gas chromatography - mass spectrometry (GC-MS). Salt concentrations were quantified using X-ray fluorescence. Both methods are described in detail in McRoberts (2011).

\subsection{Incubation experiments}

To investigate the instantaneous $\mathrm{CH}_{3} \mathrm{Br}$ emissions and the corresponding $\delta^{81} \mathrm{Br}$ isotope values pectin and Salicornia samples were heated at temperatures ranging from $30^{\circ} \mathrm{C}$ to $300^{\circ} \mathrm{C}$. Higher temperatures were not tested because methyl halide emission from this reaction pathway was expected to be of minor importance. Bjorkman and Stromberg (1997) reported losses of chlorine of $20-50 \%$ by $400^{\circ} \mathrm{C}$, which was attributed to $\mathrm{HCl}$ volatilization. Sharma et al. (2001) showed that only negligible amounts of methoxy groups are left after 10 min pyrolysis of plant material at $300^{\circ} \mathrm{C}$. This agrees with the studies of Hamilton et al. (2003) and Keppler et al. (2004) showing that pectin-related $\mathrm{CH}_{3} \mathrm{Cl}$ formation terminated at $300^{\circ} \mathrm{C}$ within the tested time span.

The plant material was filled in $4.5 \mathrm{~mm}$ inner diameter $(1 / 4 \mathrm{inch}) \mathrm{x} 150 \mathrm{~mm}$ stainless steel tubes and placed into an oven (Fig. 2). The inlet of the tube was connected to a mass flow controller delivering $20 \mathrm{~mL} / \mathrm{min}_{2}$ gas. The outlet discharged into a liquid-nitrogen-cooled stainless steel loop ( $2 \mathrm{~mm}$ inner diameter(1/8 inch) x 500 $\mathrm{mm}$ ) for trapping the emitted gases. This method of quantitative cryo-trapping has been previously shown to preserve the isotope composition of the sample (Thornton et al., 2013) and breakthrough was not observed for flow rates up to $50 \mathrm{~mL} / \mathrm{min}$. Hamilton et al. (2003) demonstrated that incubation of pectin under nitrogen atmosphere yields the same amounts of $\mathrm{CH}_{3} \mathrm{Cl}$ as in air. Consequently incubations were accomplished with nitrogen as a carrier gas to avoid difficulties due to cotrapped $\mathrm{O}_{2}$. The incubated sample size was $20 \mathrm{mg}$ for pectin and $100 \mathrm{mg}$ for Salicornia for temperatures of $150^{\circ} \mathrm{C}$ to $300^{\circ} \mathrm{C}$. At low temperatures up to $500 \mathrm{mg}$ pectin or $2 \mathrm{~g}$ Salicornia were incubated in order to trap sufficient $\mathrm{CH}_{3} \mathrm{Br}$ for isotope 
analysis. After collection the loops were sealed with Swagelok® endcaps until quantitative analysis.

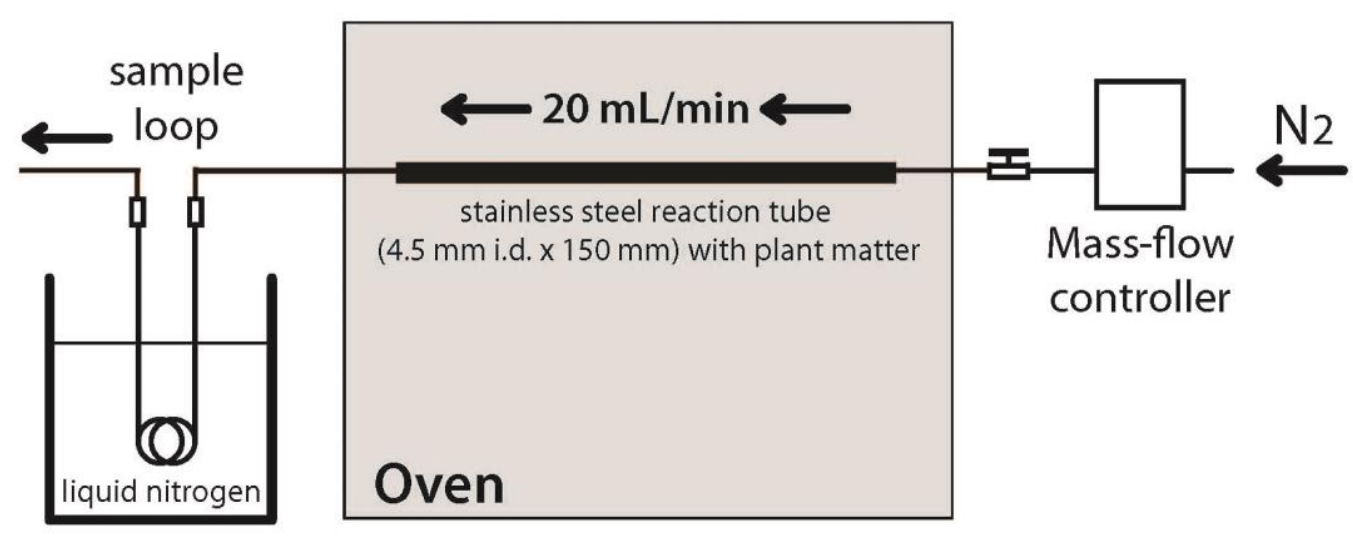

Fig. 2. Experimental setup for heating plant samples and cryogenic collection of instantaneously produced gases.

Two different experimental studies were carried out: a temperature series and a time series, in both cases designed to collect $\mathrm{CH}_{3} \mathrm{Br}$. That is, sampling of the formed $\mathrm{CH}_{3} \mathrm{Br}$ was performed during a relatively small interval of the reaction progress in terms of substrate consumption, as opposed to accumulative sampling during a longer reaction interval. For the temperature series, different samples of pectin and Salicornia were incubated for one hour at a set of temperatures spanning 110 to $230^{\circ} \mathrm{C}$. For lower temperatures, incubation/ collection times were prolonged ( 2 days for $70^{\circ} \mathrm{C}, 7$ days for $50^{\circ} \mathrm{C}$ and 21 days for $30^{\circ} \mathrm{C}$ ). At $300^{\circ} \mathrm{C}$, the incubation time was 15 min including a 5 min pre-heating time which was not collected. For the time series, samples of pectin and Salicornia were incubated at $180^{\circ} \mathrm{C}$ for 290 and 90 hours, respectively. In certain time intervals, samples from the gas stream were collected, sealed with Swagelok ${ }^{\circledR}$ endcaps, and stored until quantification and isotope analysis. 


\subsection{Quantification}

The cryoloops with the samples were connected to a gas-chromatography quadrupole mass spectrometry system (GCqMS) for quantification and purification. The complete procedure is described in detail in Thornton et al. (2013). Briefly, the GCqMS (HP5972A, Agilent ${ }^{\circledR}$, Santa Clara, CA, USA) was equipped with a packed column (60/80 Carbopack 195 B/1\% SP-1000 (polyethylene glycol); 8 ' $\mathrm{x} \frac{1}{8}$ ', steel column) for separation of the trapped compounds. The $\mathrm{CH}_{3} \mathrm{Br}$ peak was heart-cut and trapped again in a liquid nitrogen cooled stainless steel loop. A custom-made split directed 5\% of the gas stream to the MS for quantification. The MS was operated in selective ion mode for $\mathrm{CH}_{3} \mathrm{Cl}$ and $\mathrm{CH}_{3} \mathrm{Br}(\mathrm{m} / \mathrm{z} 50,52,94$ and 96). The purified sample was sealed and stored in the freezer at $-20^{\circ} \mathrm{C}$ until $\mathrm{Br}$ isotope analysis. Analytical uncertainty for the combined quantification/ purification method was usually $<5 \%$ (Thornton et al., 2013).

\subsection{Bromine isotope analysis}

The bromine isotopic composition of the plant emitted $\mathrm{CH}_{3} \mathrm{Br}$ was determined using gas-chromatography (HP 5890 Series II, Agilent ${ }^{\circledR}$, Santa Clara, CA, USA) hyphenated with multi-collector inductively coupled plasma mass spectrometry (Isoprobe ${ }^{\circledR}$, GV Instruments, Manchester, UK). The whole GC-MCICPMS method is described in detail in Horst et al. (2011). Briefly, the samples were extracted from the cryoloops using a $10 \mathrm{~mL}$ gas tight syringe (Hamilton ${ }^{\circledR}$, Reno, USA) and septa fitted at both ends of the loop. The sample was then injected into the GC system, which was equipped with a DB-624 column $\left(10 \mathrm{psi}, 70^{\circ} \mathrm{C}\right.$ isothermal). There was usually sufficient sample amount available to allow triplicate analyses. From the GC column, samples were transferred into the plasma and ionized. Two detectors (AX0 and H1) were aligned for simultaneous detection of the masses 79 and 81 . Results were recorded into an Excel ${ }^{\circledR}$ spread sheet and integrated offline using a custom-created Matlab ${ }^{\circledR}$ code. The purification and injection procedure does not cause measurable shifts in the isotopic signature (Thornton et al., 2013) 
The $\mathrm{Br}$ isotope ratio $\left(\mathrm{R}={ }^{81} \mathrm{Br} /{ }^{79} \mathrm{Br}\right)$ of a sample versus the ratio of a standard reference material is reported in per mil (\%) as:

$$
\delta^{81} \mathrm{Br}=\left(R_{\text {sample }} / R_{\text {reference }}-1\right)
$$

Bromine isotope data are referenced versus Standard Mean Ocean Bromide (SMOB). Our internal laboratory standard is a commercially available $\mathrm{CH}_{3} \mathrm{Br}$ (Sigma Aldrich ${ }^{\circledR}$ Sweden AB, Stockholm, Sweden, Catalog No. 65950) with a $\delta^{81} \mathrm{Br}$ of $+0.12 \pm 0.02 \%$. The $\mathrm{KBr}$ used for fortification of pectin has a $\delta^{81} \mathrm{Br}$ of $+0.06 \pm 0.06 \%$. Referencing of both materials versus SMOB was carried out as a commercial service by the Environmental Isotope Laboratory at the University of Waterloo (Canada) using continuous-flow isotope-ratio mass spectrometry (Shouakar-Stash et al. 2005).

\subsection{Isotope fractionation systematics}

The Rayleigh equation was used to investigate isotope fractionation processes. This equation is commonly used to investigate the partitioning behavior of isotopes between a substrate and a product reservoir as one reservoir decreases in size (Kendall and Caldwell, 1998). The remaining isotopic composition of the substrate and the instantaneous isotopic signature of the product are given in delta notation by equations 2 and 3 (e.g. Hoefs, 2004):

$$
\begin{aligned}
& \delta_{\mathrm{S}} \sim\left(\delta_{0 \mathrm{~s}}+1000\right) \cdot \mathrm{f}^{(\varepsilon / 1000)}-1000 \\
& \delta_{\mathrm{P}} \sim\left(\left(\delta_{0 \mathrm{~s}}+1000\right) \cdot \mathrm{f}^{(\varepsilon / 1000)}-1000\right)+\varepsilon
\end{aligned}
$$

where $\delta_{0 \text { s }}$ is the initial delta value of the substrate pool, $f$ is the fraction of the remaining substrate, and $\delta_{\mathrm{s}}$ is the delta value as a function of $f$. The isotope enrichment factor is denoted $\varepsilon$, and $\delta_{\mathrm{P}}$ is the delta value of the instantaneously formed product. The $\varepsilon$ value is a close approximation for the difference $\delta_{\mathrm{P}}-\delta_{\mathrm{S}}$ when the isotope fractionation is small (as in the current case for bromine isotopes) (Hoefs, 2004). 


\section{Results}

\subsection{Plant matter and blank}

Salicornia and pectin were analyzed for methoxy and (blank) salt concentrations prior to the incubation experiments (Table 1). We monitored both $\mathrm{Cl}$ (emitted as $\mathrm{CH}_{3} \mathrm{Cl}$ ) and $\mathrm{Br}$ (emitted as $\mathrm{CH}_{3} \mathrm{Br}$ ) concentrations during our experiments (Fig. EA1, Electronic Annex) although the subsequent interpretation focuses on $\mathrm{Br}$ and its isotopes. The chloride content for pectin was estimated from the cumulative yields of the time series experiment assuming $100 \%$ conversion of $\mathrm{Cl}^{-}$to $\mathrm{CH}_{3} \mathrm{Cl}$. The bromide content was calculated from the added amount of $\mathrm{KBr}$. Although pectin was only fortified with $\mathrm{KBr}$, substantial production of $\mathrm{CH}_{3} \mathrm{Cl}$ was observed (Fig. EA-1). This is likely due to the commonly used industrial extraction method for pectin from plant matter which uses acids such as $\mathrm{HCl}$ (e.g. Nanji and Chinoy, 1934). We tested for blank emissions by incubating unfortified pectin at $180^{\circ} \mathrm{C}$ for $20 \mathrm{~min}$. We found $118 \mu \mathrm{g} \mathrm{gdw}^{-1}-\mathrm{Cl}$ emitted from pectin (emitted as $\mathrm{CH}_{3} \mathrm{Cl}$ ) and $0.16 \mu \mathrm{g} \mathrm{gdw}^{-1} \mathrm{Br}$ (emitted as $\mathrm{CH}_{3} \mathrm{Br}$, gdw = grams dry weight). Whereas the production of $\mathrm{CH}_{3} \mathrm{Cl}$ was considerable, the $\mathrm{CH}_{3} \mathrm{Br}$ production was low $(0.07 \%)$ compared to yields from fortified pectin incubations for the same temperature and incubation time. Therefore, we assume that blank emissions of $\mathrm{CH}_{3} \mathrm{Br}$ are negligible for the interpretation of $\mathrm{Br}$ isotopic values of fortified pectin samples.

Tab 1 Halide and methoxy content of the plant samples

\begin{tabular}{cll}
\hline $\mathrm{mg} / \mathrm{g}$ & pectin & Salicornia \\
\hline methoxy & 82 & 16.8 \\
chloride & ${ }^{\mathrm{a}} 1.7$ & 174 \\
bromide & ${ }^{\mathrm{b}} 6.7$ & 0.75 \\
\hline
\end{tabular}

${ }^{a}$ value was estimated from cumulative $\mathrm{CH}_{3} \mathrm{Cl}$ emissions

${ }^{\mathrm{b}}$ amount of added $\mathrm{Br}$ 


\subsection{Temperature series experiment}

For the first experimental series, incubations were carried out for different samples of Salicornia and $\mathrm{KBr}$-fortified pectin for temperatures ranging from 30 to $300^{\circ} \mathrm{C}$. The corresponding incubation times ranged from $21 \mathrm{~d}$ to $15 \mathrm{~min}$ respectively. The $\delta^{81} \mathrm{Br}$ of $\mathrm{CH}_{3} \mathrm{Br}$ that was emitted from both types of plant matter is largely similar over the tested temperature range (Fig. 3). Pectin emissions show an average $\delta^{81} \mathrm{Br}$ of $-1.94 \pm 0.23 \%$ o $(n=8)$. The $300^{\circ} \mathrm{C}$ sample shows a significantly higher value of $-1.38 \pm 0.21 \%$. At this temperature, ca $50 \%$ of the substrate $\mathrm{Br}$ ( $\mathrm{KBr}$ salt) was converted compared to $<10 \%$ conversion of the $\mathrm{KBr}$ salt at the lower temperatures. The emission rates were determined for some of the temperature steps (Table EA1). The $\delta^{81} \mathrm{Br}$ of $\mathrm{CH}_{3} \mathrm{Br}$ emitted from Salicornia has an average of $-1.82 \pm 0.02 \%$ $(n=4)$. Not more than $11 \%$ of the substrate salt was transformed at the highest temperature $\left(300^{\circ} \mathrm{C}\right)$ in this case. The $\delta^{81} \mathrm{Br}$ of salts in Salicornia could not be measured for this study but might be similar to the $\mathrm{Br}$ isotopic composition of the salt used to fortify pectin ( $\sim \%$ o). Halophytes are exposed to marine salts with a $\delta^{81} \mathrm{Br}$ of $0 \%$ SMOB and have been shown to accumulate that salt (Zafrilla et al., 2010). Consequently, an isotopic shift of ca. $-2 \%$ was observed in the studied temperature range for both fortified pectin and Salicornia, with large fractions remaining ( $f>0.9$; Eq. 2 and 3). 


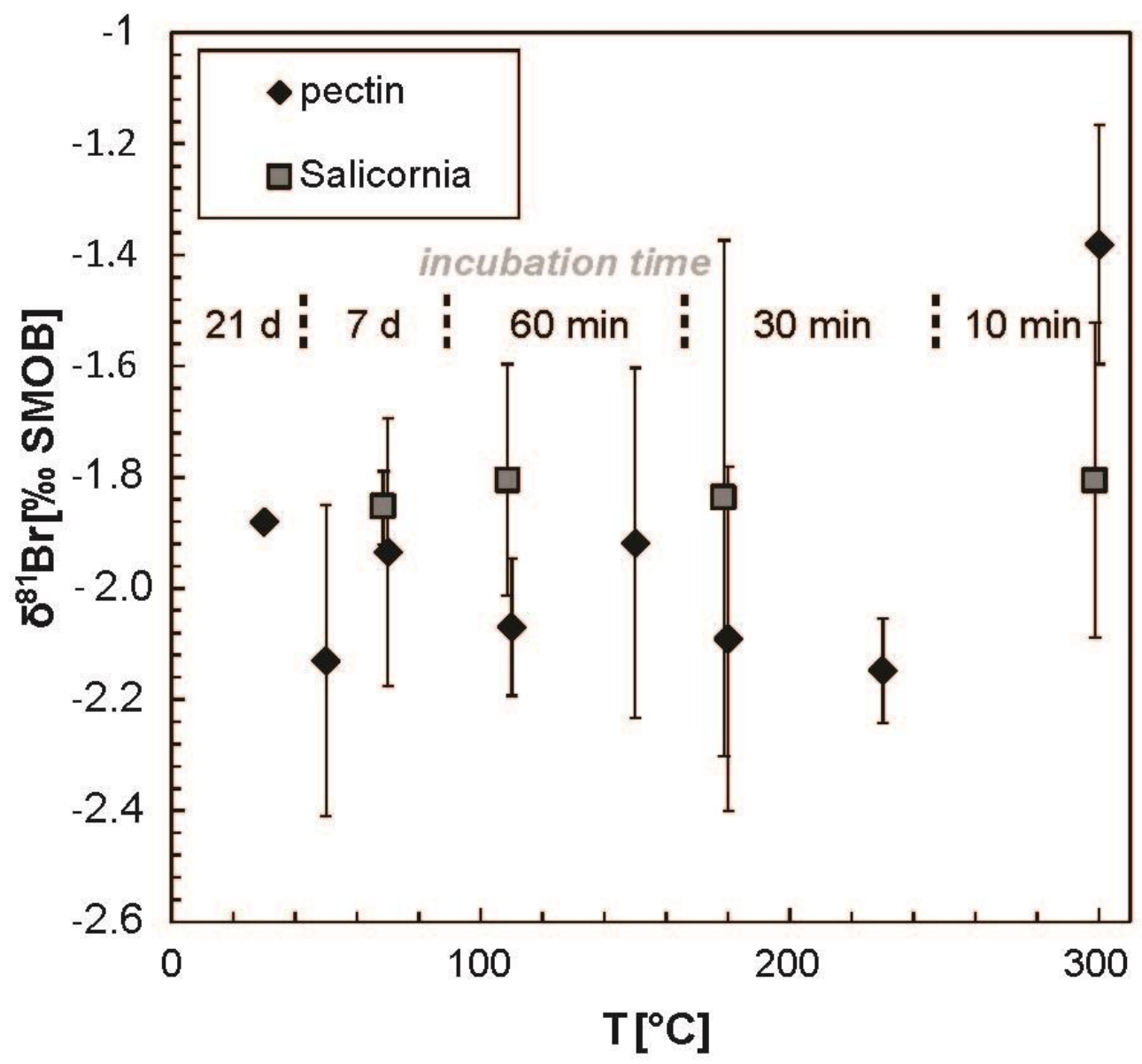

Fig. 3. Pectin and Salicornia fruticosa $\delta^{81} \mathrm{Br}-\mathrm{CH}_{3} \mathrm{Br}$ values as a function of incubation temperature. The temperature range was from $30^{\circ} \mathrm{C}$ to mimic near-ambient emissions and up to $300^{\circ} \mathrm{C}$ to mimic emissions from smoldering biomass/vegetation burning. The values represent emissions during large fractions of remaining salt $(f>0.9)$ (except for the $300^{\circ} \mathrm{C}$ pectin sample) to allow estimation of the isotope enrichment factor $\varepsilon$ (without effects of substantial shifts in isotopic composition of the $\mathrm{Br}$ source reservoir). Error bars represent the standard deviation for $\mathrm{n}=3$ isotope analyses. The $30^{\circ} \mathrm{C}$ value represents single isotope analyses.

\subsection{Time-series experiment}

Samples of pectin and Salicornia were continuously incubated at $180^{\circ} \mathrm{C}$ and discrete subsamples of the emitted gas were collected after certain time intervals, representing instantaneously formed $\mathrm{CH}_{3} \mathrm{Br}$. Emission rates and $\mathrm{Br}$ isotope composition were determined for $\mathrm{CH}_{3} \mathrm{Br}$ (Fig. 4; rates of $\mathrm{CH}_{3} \mathrm{Cl}$ emission in the Electronic Annex, Fig. EA-1). The rates of $\mathrm{CH}_{3} \mathrm{Br}$ formation were highest in the initial phase of the incubation, for Salicornia decreasing from 15.8 to $0.5 \mu \mathrm{g} \mathrm{gdw}$ ${ }^{1} \cdot \mathrm{h}^{-1} \mathrm{Br}$ (microgram $\mathrm{Br}$ per hour and gram dry-weight of plant matter) after 90 hours 
(calculated from $\mathrm{CH}_{3} \mathrm{Br}$ emissions). For fortified pectin, rates decreased from 643 to $2.6 \mu \mathrm{g} \mathrm{gdw}^{-1} \cdot \mathrm{h}^{-1} \mathrm{Br}$ after 100 hours. Thus, initial rates from the pectin incubation were higher and decreased faster than the rates obtained from Salicornia. In pectin $85 \%$ of the initial substrate $\mathrm{Br}$ was converted to $\mathrm{CH}_{3} \mathrm{Br}$ after $100 \mathrm{~h}$, whereas only $30 \%$ was transformed in Salicornia (Figure 4b). This may be explained by the lower methoxy content (by a factor 5) and the considerable high chloride content in the latter material, thus putting a stoichiometric constraint on the reaction, i.e. $\mathrm{Cl}$ is limiting the availability of methoxy groups for $\mathrm{Br}$.

The Br isotopic composition changed over time. Both Salicornia and pectin-derived $\mathrm{CH}_{3} \mathrm{Br}$ show the most depleted values of $\sim-2 \%$ in the initial phase of heating when the production rates are highest. After $10 \mathrm{~h}$ (for pectin) to $20 \mathrm{~h}$ (for Salicornia) $\delta^{81} \mathrm{Br}$ values become less depleted and maintain the isotopic composition over the remaining time. Pectin-derived $\mathrm{CH}_{3} \mathrm{Br}$ samples show $\delta^{81} \mathrm{Br}$ values of ca $0 \%$ at later incubation stages. Incubations with pectin were continued until 290 hours but no further changes in $\delta^{81} \mathrm{Br}$ values were observed. $\mathrm{Br}$ isotopic values of $\mathrm{CH}_{3} \mathrm{Br}$ from Salicornia increase to values of $\sim-1 \%$ within the tested time range. Taken together, the results show a decrease in $\mathrm{CH}_{3} \mathrm{Br}$ production at longer incubation times, which is accompanied by increasingly higher isotopic values in the product. 

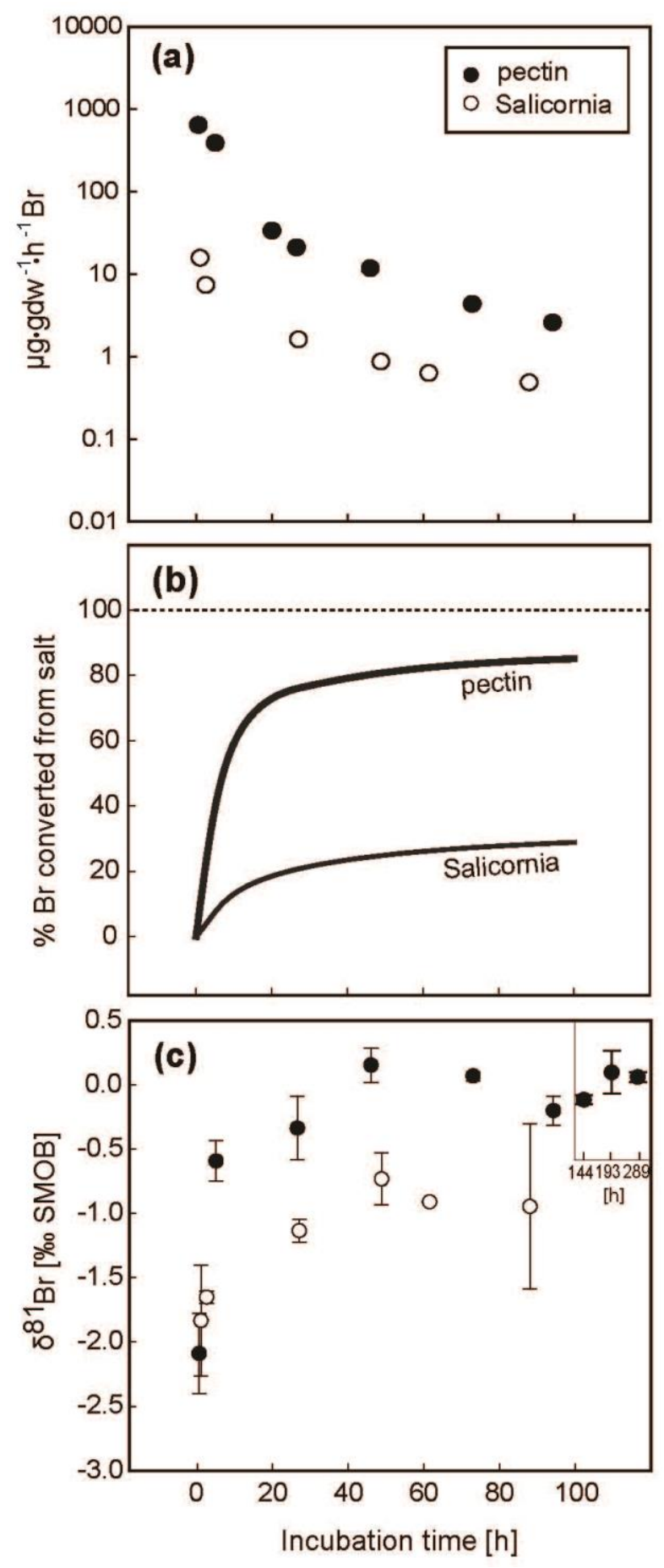

Fig. 4. (a) Rates of $\mathrm{Br}$ (released as $\mathrm{CH}_{3} \mathrm{Br}$ ) emissions at $180^{\circ} \mathrm{C}$ from Salicornia fruticosa and fortified pectin for the individual samples (time series). (b) Cumulative amounts of $\mathrm{Br}$ released as $\mathrm{CH}_{3} \mathrm{Br}$ from Salicornia and pectin (as \% converted from the salt). Amounts between the individual samples were interpolated. The dotted grey line marks the theoretical complete conversion of $\mathrm{Br}$ salt to $\mathrm{CH}_{3} \mathrm{Br}$ (c) Measured instantaneous $\delta^{81} \mathrm{Br}$ values in $\mathrm{CH}_{3} \mathrm{Br}$ from Salicornia and pectin. 


\section{Discussion}

\subsection{Evaluation of isotope fractionation behavior}

The isotopic values changed over the course of the time-series experiment (Fig. 4c). The most likely reason is the gradual emptying of the salt substrate pool and the accompanying ${ }^{81} \mathrm{Br}$ enrichment in the remaining substrate pool. To investigate this, the Rayleigh equations 2 and 3 were used to calculate the $\delta^{81} \mathrm{Br}$ value of the remaining salt substrate and the $\delta^{81} \mathrm{Br}$ value of the $\mathrm{CH}_{3} \mathrm{Br}$ instantaneously emitted at any given time. The initial delta value of the $\mathrm{KBr}$ salt was known $\left(\delta_{0 \mathrm{~s}}=+0.06 \%\right.$ o SMOB), as was the instantaneous $\delta^{81} \mathrm{Br}$ of $\mathrm{CH}_{3} \mathrm{Br}\left(\delta_{\mathrm{P}}\right)$ for large fractions remaining $(f>0.9)$, based on the temperature series (excluding the data point for incubation at $\left.300^{\circ} \mathrm{C}\right)$. The average enrichment factor was derived from the difference $\delta_{\mathrm{P}}-\delta_{\mathrm{s}}$ between the product and the substrate, yielding an $\varepsilon$ of $-2.0 \pm 0.23 \%$ o $(1 \mathrm{~s}, \mathrm{n}=8)$ for pectin and $-1.8 \pm 0.02 \%$ o $(1 \mathrm{~s}, \mathrm{n}=4)$ for Salicornia (assuming a salt $\delta^{81} \mathrm{Br}$ of $0 \%$ ). The Rayleigh plots in Fig. 5 show the theoretical development of $\mathrm{Br}$ isotopic signatures of the salt substrate pool (black lines) and the instantaneously produced $\mathrm{CH}_{3} \mathrm{Br}$ (grey lines) assuming that the obtained isotope enrichment factors are constant over the whole range of $f$. Figure 5 also illustrates the measured samples from the time series experiment. For Salicornia, only $30 \%$ of the substrate was transformed $(f=$ 0.7 ) and the $\delta^{81} \mathrm{Br}$ of the instantaneous product $\mathrm{CH}_{3} \mathrm{Br}$ follows the Rayleigh curve within analytical uncertainty for most of the samples. Pectin-derived $\mathrm{CH}_{3} \mathrm{Br}$ follows the Rayleigh curve for the instantaneous product until ca. 50\% of the substrate is consumed, but for small remaining $f$ the $\delta^{81} \mathrm{Br}$ values are lower than predicted by the Rayleigh model. Fitting of the Rayleigh curve to the pectin data leads to a $\varepsilon$ of only $-0.9 \%$ o $\left(\mathrm{R}^{2}=0.78\right)$. Aside from not matching the data from the temperature series, this $\varepsilon$ of $-0.9 \%$ and the initial product $\delta^{81} \mathrm{Br}$ of $-1.9 \%$ would force the salt $\delta^{81} \mathrm{Br}$ to $-1.0 \%$ (in contrast to the measured $\delta^{81} \mathrm{Br}$ of $+0.06 \%$ ). Moreover, the temperature-series $\varepsilon$ was derived from 4 to 7 individual samples incubated at different temperatures whereas the time series was carried out using one sample of plant matter only. Hence, this smaller $\varepsilon$ is rejected in favor of the obtained $\varepsilon$ of $2.0 \%$ for pectin and $-1.8 \%$ for Salicornia. 
It is unclear why we observed this atypical enrichment pattern for the pectin samples, and if a reaction process, or combination of more than one reaction, exists that would produce such a pattern. We were not able to analyze the $\mathrm{KBr}$ salt pool, during its gradual depletion, to confirm that the reaction progressed as anticipated (with respect to $f$ ), and investigate its concomitant isotopic evolution. The methods for isotope analysis (Horst et al., 2011) and cryo-sampling (Thornton et al., 2013) have been tested rigorously for isotope-conservative characteristics; these have been found not to induce any systematic shifts in the $\delta^{81} \mathrm{Br}$ of the sample. It is possible that the very long incubations of plant matter caused unexpected changes in the reaction, and the isotopic composition, of a type not reported in the literature so far. Another conceivable explanation is a non-steady state isotope effect due to an emerging rate limiting step or change of reaction mechanism (Maggi and Riley, 2009). The $\delta^{81} \mathrm{Br}$ of the pectin data points at $f=0.1-0.2$ (Figure 5) would, if assumed to be accurate and representative of the studied reaction, result from a larger isotope fractionation than that of the first two data points ( $f$ in the range 0.5 0.9) because production of isotopically lighter $\mathrm{CH}_{3} \mathrm{Br}$ plotting below the Rayleigh curve would result in an even stronger enrichment of heavier isotopes in the salt substrate. The observed pattern could potentially indicate a shift in bromide source pools (e.g. from hydrogen bonded to dissolved bromide; Fig. 1a vs. 1b reaction mechanisms) and in the associated $\varepsilon$ value, or the emergence of an additional parameter acting as a hitherto masked rate-limiting step (Elsner et al., 2005). 


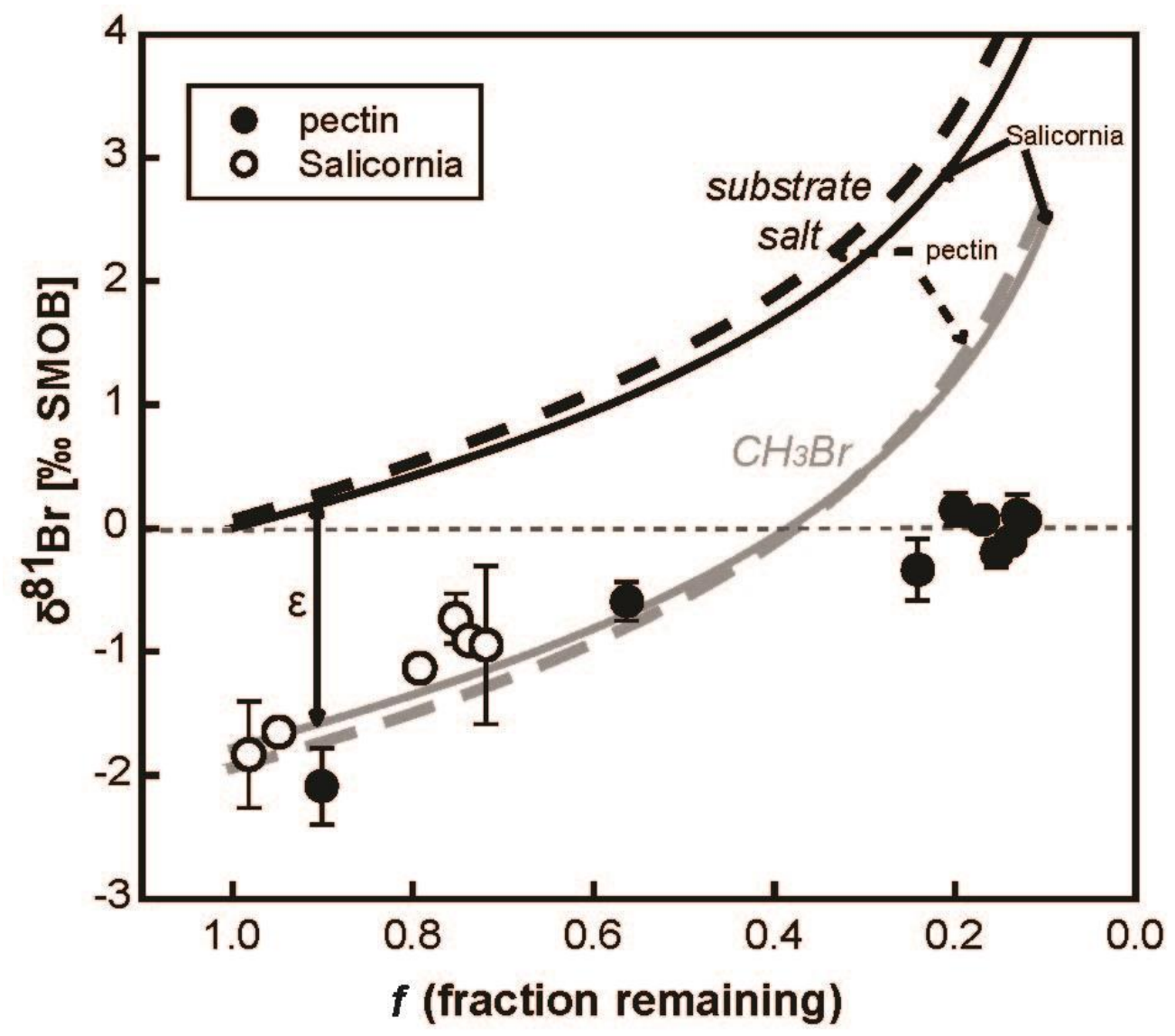

Fig. 5: Rayleigh plots calculated using Equation 2 for the salt substrate (black) and using equation 3 for the $\mathrm{CH}_{3} \mathrm{Br}$ as a product (grey) for pectin (dashed, $\varepsilon=-2.0 \%$ ) and Salicornia (straight, $\varepsilon=-$ $1.8 \%$ ) respectively. The grey graphs represent the isotopic value of the instantaneous product. Enrichment factors were obtained from the temperature series experiment. The included samples are the results from the time series experiment.

\subsection{Isotopic fingerprint of a potential source signature}

The major objective of this study was to constrain the endmember $\delta^{81} \mathrm{Br}$ signature for $\mathrm{CH}_{3} \mathrm{Br}$ produced with pectin as the methoxy-group source. This mechanism may be equally important to the formation of $\mathrm{CH}_{3} \mathrm{Br}$ from lignin in woody plants, which is active at high temperatures, e.g. during smoldering biomass burning, and has been suggested to add about $10 \%$ of $\mathrm{CH}_{3} \mathrm{Br}$ to the atmospheric budget (Andreae and Merlet, 2001). Pectin is the dominant source from non-woody plants at ambient and higher temperatures (up to ca. $300^{\circ} \mathrm{C}$ ), and pectin-based sources such as decomposition of senescent plant material can be expected to be widespread (Hamilton et al., 2003). 
The isotope signature of the low-temperature emissions is represented by the $\delta^{81} \mathrm{Br}$ $\mathrm{CH}_{3} \mathrm{Br}$ in the temperature series experiment, i.e. -1.8 to $-2.0 \%$. The $\delta^{81} \mathrm{Br}^{-} \mathrm{CH}_{3} \mathrm{Br}$ values were almost constant over the investigated temperature range of 30 to $300^{\circ} \mathrm{C}$ for $f>0.9$. Environmental shifts of this isotope endmember are difficult to predict, but could result from e.g. a reduction of $f$ due to conversion of inorganic bromide to organobromine compounds (Leri and Myneni, 2012). However, the herein studied reaction is by itself robust with respect to the $\delta^{81} \mathrm{Br}-\mathrm{CH}_{3} \mathrm{Br}$. To illustrate, a sample incubated at $110{ }^{\circ} \mathrm{C}$ revealed no significant shift in $\delta^{81} \mathrm{Br}-\mathrm{CH}_{3} \mathrm{Br}$ when incubated for a time period of $1 \mathrm{~h}$ (where f 0.9995) compared to $33 \mathrm{~h}$ (f $\sim 0.96$; average $\delta^{81} \mathrm{Br}$ of $-2.1 \pm 0.12 \%$, $\mathrm{n}=5$ ). Indeed, eq. 3 gives that the instantaneous $\delta^{81} \mathrm{Br}-\mathrm{CH}_{3} \mathrm{Br}$ changes only by ca $0.2 \%$ until $f=0.9$. At ambient temperatures the reaction would be even slower. Emitted $\mathrm{CH}_{3} \mathrm{Br}$ would have a constant $\delta^{81} \mathrm{Br}$ for almost a year (at a temperature of $30^{\circ} \mathrm{C}$ ), if our data were extrapolated with the approximation that the reaction rate at least doubles with every $10 \mathrm{~K}$ of temperature (according to the Arrhenius equation; e.g., Atkins, 2001).

High temperature $\mathrm{CH}_{3} \mathrm{Br}$ emissions from e.g. biomass burning may exhibit a different $\varepsilon$ value from that obtained in this study, since the reaction mechanism and the methoxy source (e.g. lignin for woody plants instead of pectin) may not be the same. Furthermore, such emissions may have a more variable $\delta^{81} \mathrm{Br}$ signature due to the temperature effect on the reaction rate, and the corresponding consumption of the salt (i.e. large decrease in $f$ in eq. 2 and 3). To illustrate, $50 \%$ of the $\mathrm{KBr}$ salt was consumed already after $10 \mathrm{~min}$ incubation of pectin at $300^{\circ} \mathrm{C}$, resulting in a $\delta^{81} \mathrm{Br}$ of $-1.4 \%$ (instead of $-2.0 \%$ o for $f>0.9$ ). Another effect that adds variability to the $\delta^{81} \mathrm{Br}-\mathrm{CH}_{3} \mathrm{Br}$ is the decomposition of methoxy groups at high temperatures, thus halting the methylation reaction. This was tested at $300^{\circ} \mathrm{C}$ by three samples in sequence. Whereas $50.6 \%$ of the $\mathrm{KBr}$ was consumed during the first $10 \mathrm{~min}$, only an additional $0.4 \%$ were transformed during the next $10 \mathrm{~min}$, and as little as $0.07 \%$ in the third $10 \mathrm{~min}$ interval. Complete consumption of the salt could not be achieved and the cumulative $\delta^{81} \mathrm{Br}-\mathrm{CH}_{3} \mathrm{Br}$ is likely to stay close to $-1.4 \%$ for this sample. However, most terrestrial plants (except for halophytes) have $\mathrm{Br}$ concentrations at 
the lower ppm range and thus all $\mathrm{Br}$ might be completely converted to $\mathrm{CH}_{3} \mathrm{Br}$ before all of the methoxy groups are decomposed. Therefore we suggest a range of 0 to $2 \%$ SMOB for high temperature conversion, which comprises both plants with low and higher Br contents.

\subsection{A two-dimensional view of $\mathrm{CH}_{3} \mathrm{Br}$ with existing $\delta^{13} \mathrm{C}$ and $\delta^{81} \mathrm{Br}$ signatures}

Relatively few isotope studies have been carried out on ambient methyl bromide largely due to the substantial analytical challenges. Fingerprints of $\delta^{13} \mathrm{C}$ have been determined for industrially produced $\mathrm{CH}_{3} \mathrm{Br}$ (McCauley et al., 1999), salt marsh emissions (Bill et al., 2002) and atmospheric $\mathrm{CH}_{3} \mathrm{Br}$ (Bill et al., 2004; Bahlmann et al., 2011). Fingerprints of $\delta^{81} \mathrm{Br}$ have been measured previously for industrial (Horst et al., 2011) and atmospheric $\mathrm{CH}_{3} \mathrm{Br}$ (Horst et al., 2013). Figure 6 shows the current state of combined $\delta^{13} \mathrm{C}-\delta^{81} \mathrm{Br}$ isotopic ranges for potential sources based on all available measurements to date. The $\delta^{13} \mathrm{C}$ values for $\mathrm{CH}_{3} \mathrm{Br}$ released during biomass burning from rice plants have been measured to range from -46 to $-53 \%$ (Komatsu et al. 2005). These data are consistent with previous data by Keppler et al. (2004) showing that ${ }^{13} \mathrm{C}$-depleted methoxy groups are the major parent organic matter of methyl chloride $\left(\mathrm{CH}_{3} \mathrm{Cl}\right)$ formation. The carbon pool (methoxy groups) of $\mathrm{CH}_{3} \mathrm{Br}$ formation is considered to be the same as for $\mathrm{CH}_{3} \mathrm{Cl}$. Although the isotopic shift may be different (Komatsu et al. (2004) observed 8\%o difference between $\delta^{13} \mathrm{C}$ values of $\mathrm{CH}_{3} \mathrm{Br}$ and $\mathrm{CH}_{3} \mathrm{Cl}$ ) because of differing reaction kinetics, the relative difference between low and high temperature emitted $\mathrm{CH}_{3} \mathrm{Br}$ might be similar and the $\delta^{13} \mathrm{C}-\mathrm{CH}_{3} \mathrm{Cl}$ values are a good first estimate for what $\delta^{13} \mathrm{C}$ values to be anticipated for $\mathrm{CH}_{3} \mathrm{Br}$. 


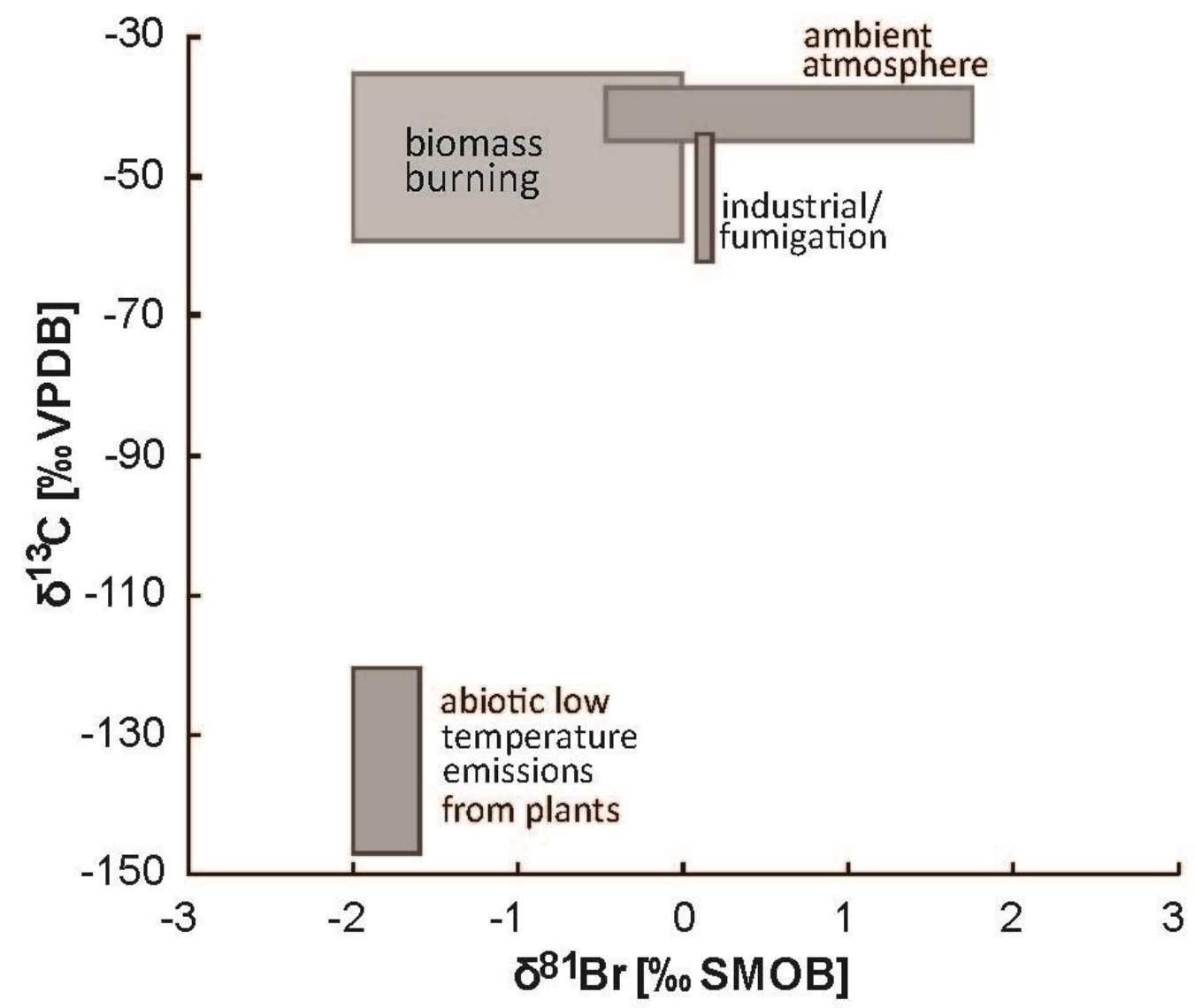

Fig. 6. Reported isotopic ranges of $\delta^{13} \mathrm{C}$ and $\delta^{81} \mathrm{Br}$ in methyl bromide in ambient atmosphere and from various source reservoirs. Stable carbon isotope values for plant emissions are estimated from $\mathrm{CH}_{3} \mathrm{Cl}$ analyses (Keppler et al., 2005 and references therein). The $\delta^{81} \mathrm{Br}$ values for low and high temperature emissions are related to a source signature (salt) of $\sim 0 \%$ SMOB.

The currently known and assumed ranges of stable carbon and bromine isotopes in $\mathrm{CH}_{3} \mathrm{Br}$ for different sources and reservoirs are summarized in Figure 6. Whilst $\delta^{81} \mathrm{Br}-\mathrm{CH}_{3} \mathrm{Br}$ values of industrial sources are within the range of those recently measured for the atmosphere (Horst et al., 2013) $\delta^{81} \mathrm{Br}^{-} \mathrm{CH}_{3} \mathrm{Br}$ values released from dry plant matter at low and high temperatures are up to 4\%o lighter. These results might already imply that, if emissions from senescent and dead plants including biomass burning are globally significant, then a substantial kinetic isotope effect should be associated with the decomposition of $\mathrm{CH}_{3} \mathrm{Br}$ in the environment. The isotopic effects associated with perceived major sinks such as uptake by the oceans, soils and reaction of $\mathrm{OH}$ radicals in the troposphere which could cause isotope shifts 
need to be studied. Horst et al., (2013) calculated a field-based $\delta^{81} \mathrm{Br}$ enrichment factor of $-4.7 \pm 3.7 \%$ based on $\delta^{81} \mathrm{Br}-\mathrm{CH}_{3} \mathrm{Br}$ measurements in atmospheric samples. The $\varepsilon$ might represent the combined isotopic shift caused by these major sinks. Gola et al., (2005) found a stable carbon isotope enrichment factor of $59 \%$ for a $\mathrm{CH}_{3} \mathrm{Cl}$ reaction with $\mathrm{OH}$ radicals. Both enrichment factors would have to be considered in order to find the original source signatures and to calculate the corresponding fraction remaining. This assessment only provides a first overview of known source ranges, but it shows that two-dimensional isotope analysis of $\delta^{13} \mathrm{C}$ and $\delta^{81} \mathrm{Br}$ might be able to resolve potential sources from known atmospheric signatures. It is also important to note that two potentially large sources - the oceans and living plants have not been investigated yet for both $\delta^{81} \mathrm{Br}-\mathrm{CH}_{3} \mathrm{Br}$ and $\delta^{13} \mathrm{C}-\mathrm{CH}_{3} \mathrm{Br}$ values. Future investigations, including constraining the stable bromine and carbon isotope signatures of these sources and the most important sinks, has the potential to improve our picture of the global $\mathrm{CH}_{3} \mathrm{Br}$ budget. Furthermore, recent development of $\delta^{2} \mathrm{H}$ analysis in $\mathrm{CH}_{3} \mathrm{Cl}$ emitted from plants (Greule et al., 2012) now opens the door for three-dimensional isotope analysis of methyl halides.

\section{Conclusions}

This study investigated the stable bromine isotopic composition of abiotically emitted $\mathrm{CH}_{3} \mathrm{Br}$ from plant matter. Results show that the $\mathrm{Br}$ isotopic composition of the formed methyl bromide can be expected to be relatively constant over a wide temperature range and for incomplete reactions. The enrichment factor of ca. $-2 \%$ (incomplete reaction) makes it a useful tool to identify emissions from halophytic plants. Similar fractionations may also be assumed for non-halophytic plants. Emissions from biomass burning possibly comprise a wider range of ca 0 to $-2 \%$ for the cumulative product if $\mathrm{Br}$-salt conversion approaches completion and provided the salt $\delta^{81} \mathrm{Br}$ is $0 \%$ SMOB. Salicornia showed a similar enrichment factor as observed for pectin when heated at the same temperature. Therefore we suggest that this enrichment factor is characteristic for the pectin-salt reaction pathway in natural plant matter. However, $\mathrm{CH}_{3} \mathrm{Br}$ emissions from other plant 
species should be studied to confirm these findings. Furthermore it would be important to investigate concentrations and isotopes of $\mathrm{CH}_{3} \mathrm{Br}$ formed from woody plant matter at high temperatures in order to get an insight into the magnitude of formation from the lignin-salt production pathway. Together with the findings of this study, a combined source signature for both pathways could be determined. This in combination with other stable isotopes such as carbon or hydrogen might provide a clearer picture of the dimension of this source and its importance for the atmospheric $\mathrm{CH}_{3} \mathrm{Br}$ budget.

\section{Acknowledgements}

This research was funded by the Swedish Research Council (VR grant 311-20078381). Örjan Gustafsson acknowledges financial support as an Academy Research Fellow from the Swedish Royal Academy of Sciences through a grant from the Knut and Alice Wallenberg Foundation. Brett Thornton acknowledges post-doc funding from the Bolin Centre for Climate Research. Frank Keppler was supported by the ESF (EURYI Award to F.K.) and DFG (KE 884/2-1) and by the DFG research unit 763 'Natural Halogenation Processes in the Environment Atmosphere and Soil' (KE 884/7-1). We thank Colin McRoberts (Queen's University, Belfast) for analyses of the methoxy content.

\section{References}

Andreae M. O., and Merlet P. (2001) Emission of trace gases and aerosols from biomass burning, Glob. Biogeochem. Cycle, 15(4), 955-966, doi:10.1029/2000GB001382.

Atkins P. (2001) Atkins' Physical Chemistry, $7^{\text {th }}$ ed., Oxford University Press, Oxford

Bahlmann E., Weinberg I., Seifert R., Tubbesing C. and Michaelis W. (2011) A high volume sampling system for isotope determination of volatile halocarbons and hydrocarbons. Atmos. Meas. Tech., 4, 2073-2086 
Bill M., Rhew R. C., Weiss R. F. and Goldstein A. H. (2002) Carbon isotope ratios of methyl bromide and methyl chloride emitted from a coastal salt marsh, Geophys. Res. Lett., 29, 4 pp., doi:200210.1029/2001GL012946.

Bill M., Conrad M. E. and Goldstein A. H. (2004) Stable carbon isotope composition of atmospheric methyl bromide, Geophys. Res. Lett., 31(4), doi:10.1029/2003GL018639.

Bjorkman E. and Stromberg B. (1997) Release of chlorine from biomass at pyrolysis and gasification conditions, Energy Fuels, 11(5), 1026-1032, doi:10.1021/ef970031o.

Blei E., Hardacre C. J., Mills G. P., Heal K. V. and Heal M. R. (2010) Identification and quantification of methyl halide sources in a lowland tropical rainforest, Atmospheric Environment, 44(8), 1005-1010.

Blei E. and Heal M. R. (2011) Methyl bromide and methyl chloride fluxes from temperate forest litter, Atmos. Environ., 45(8), 1543-1547, doi:10.1016/j.atmosenv.2010.12.044.

Butler J. H. (2000), Atmospheric chemistry: Better budgets for methyl halides?, Nature, 403(6767), 260-261.

Bernstein A., Ronen Z., Levin E., Halicz L., Gelman F. (2013) Kinetic bromine isotope effect: example from the microbial debromination of brominated phenols. Anal. Bioanal. Chem., 405, 2923-2929.

Butler J. H., King D. B., Lobert J. M., Montzka S. A., Yvon-Lewis S. A., Hall B. D., Warwick N. J., Mondeel D. J., Aydin M. and Elkins J. W. (2007) Oceanic distributions and emissions of short-lived halocarbons, Glob. Biogeochem. Cycle, 21(1), doi:10.1029/2006GB002732.

Carrizo, D., Holmstrand H., Unger M., Andersson, P., Gustafsson O., Sylva S., Reddy C. (2011) Compound-specific bromine isotope composition of industrially sybthesized and one natural organobromine substances, Env. Chem, 8, 127-132.Derendorp L., Wishkerman A., Keppler F., McRoberts C., Holzinger R. and Rockmann T. (2012) Methyl chloride emissions from halophyte leaf litter: Dependence on temperature and chloride content, Chemosphere, 87(5), 483-489, doi:10.1016/j.chemosphere.2011.12.035.

Elsner M., Zwank L., Hunkeler D. and Schwarzenbach R.P. (2005) A new concept linking observable stable isotope fractionation to transformation pathways of organic pollutants, Environ. Sci.Technol., 39, 6896-6916 
Gan J., Yates S. R., Ohr H. D., Sims J. J. (1998) Production of methyl bromide by terrestrial higher plants, Geophys. Res. Lett., 25, 3595-3598.

Gebhardt S., Colomb A., Hofmann R., Williams J. and Lelieveld J. (2008) Halogenated organic species over the tropical South American rainforest, Atmos. Chem. Phys., 8(12), 3185-3197.

Gola A. A., D’Anna B., Feilberg K. L., Sellevåg S. R., Bache-Andreassen L. and Nielsen C. J. (2005) Kinetic isotope effects in the gas phase reactions of $\mathrm{OH}$ and $\mathrm{Cl}$ with $\mathrm{CH} 3 \mathrm{Cl}, \mathrm{CD} 3 \mathrm{Cl}$, and $13 \mathrm{CH} 3 \mathrm{Cl}$, Atmos. Chem. Phys., 5(9), 23952402, doi:10.5194/acp-5-2395-2005.

Greule M., Huber S. G. and Keppler F. (2012) Stable hydrogen-isotope analysis of methyl chloride emitted from heated halophytic plants, Atmos. Environ., 62, 584-592, doi:10.1016/j.atmosenv.2012.09.007.

Hamilton J., McRoberts W., Keppler F., Kalin R. and Harper D. (2003) Chloride methylation by plant pectin: An efficient environmentally significant process, Science, 301(5630), 206-209.

Harper D. B. (1985) Halomethane from halide ion - a highly efficient fungal conversion of environmental significance, Nature, 315(6014), 55-57.

Hoefs J. (2004) Stable Isotope Geochemistry, $5^{\text {th }}$ ed., Springer, Berlin, 244 p.

Horst A., Holmstrand H., Andersson P., Andersson A., Carrizo D., Thornton B. F. and Gustafsson O. (2011) Compound-specific bromine isotope analysis of methyl bromide using gas chromatography hyphenated with inductively coupled plasma multiple-collector mass spectrometry, Rapid Commun. Mass Spectrom., 25(17), 2425-2432, doi:10.1002/rcm.5144.

Horst A., Thornton B. F., Holmstrand H., Andersson P., Crill P. M. and Gustafsson O., Stable bromine isotopic composition of atmospheric $\mathrm{CH}_{3} \mathrm{Br}$, accepted for publication in TellusB $20^{\text {th }}$ August 2013

Kendall C. and Caldwell E.A. (1998) Fundamentals of Isotope Geochemistry in Isotope Tracers in Catchment Hydrology, Elsevier Science B.V., Amsterdam. pp. 51-86

Keppler F., Kalin R. M., Harper D. B., McRoberts W. C. and Hamilton J. T. G. (2004) Carbon isotope anomaly in the major plant C1 pool and its global biogeochemical implications, Biogeosciences, 1(2), 123-131, doi:10.5194/bg1-123-2004. 
Keppler F., Harper D. B., Rockmann T., Moore R. M. and Hamilton J. T. G. (2005) New insight into the atmospheric chloromethane budget gained using stable carbon isotope ratios, Atmos. Chem. Phys., 5, 2403-2411.

Khan M. A., Gul B. and Weber D. J. (2001) Effect of salinity on the growth and ion content of Salicornia rubra, Commun. Soil Sci. Plant Anal., 32(17-18), 29652977, doi:10.1081/CSS-120000975.

King D. B., Butler J. H., Yvon-Lewis S. A. and Cotton S. A. (2002) Predicting oceanic methyl bromide saturation from SST, Geophys. Res. Lett., 29(24), doi:10.1029/2002GL016091.

Leri A. C. and Myneni S. C. B. (2012) Natural organobromine in terrestrial ecosystems, Geochim. Cosmochim. Acta, 77, 1-10, doi:10.1016/j.gca.2011.11.012.

Maggi F. and Riley W.J. (2009) Transient competitive complexation in biological kinetic isotope fractionation explains nonsteady isotope effects: Theory and application to denitrification in soils, J. Geophys. Res.-Biogeo 114, G04012, doi:10.1029/2008JG000878

McCauley S. E., Goldstein A. H. and DePaolo D. J. (1999), An isotopic approach for understanding the $\mathrm{CH}_{3} \mathrm{Br}$ budget of the atmosphere, Proc. Natl. Acad. Sci. U.S.A., 96(18), 10006.

McRoberts W. C. (2011) Investigation of the chemistry of the demethylation of pectin by halide ion. PhD thesis, Queen's University, Belfast, $332 \mathrm{p}$.

Montzka S. A., Reimann S., Engel A., Krüger K., O’Doherty S. and Sturges W. T. (2011) Ozone-depleting substances (ODSs) and related chemicals, in: Scientific Assessment of Ozone Depletion: 2010, Global Ozone Research and Monitoring Project, Report No. 52, Chapt. 1, edited by: World Meteorological Organization, Geneva, Switzerland

Myneni S. C. B. (2002) Formation of stable chlorinated hydrocarbons in weathering plant material, Science, 295(5557), 1039-1041, doi:10.1126/science.1067153.

Nanji H.R. and Chinoy J.J. (1934) A simple method for the purification of Citrus pectin, Biochem.J., 28, 456-462

Rhew R. C., Miller B. R. and Weiss R. F. (2000) Natural methyl bromide and methyl chloride emissions from coastal salt marshes, Nature, 403(6767), 292295, doi:10.1038/35002043. 
Rudolph J., Lowe D. C., Martin R. J. and Clarkson T. S. (1997), A novel method for compound specific determination of delta $\mathrm{C}-13$ in volatile organic compounds at ppt levels in ambient air, Geophys. Res. Lett., 24(6), 659-662, doi:10.1029/97GL00537.

Saito T. and Yokouchi Y. (2006) Diurnal variation in methyl halide emission rates from tropical ferns, Atmos. Environ., 40(16), 2806-2811, doi:10.1016/j.atmosenv.2006.01.016.

Saito T. and Yokouchi Y. (2008) Stable carbon isotope ratio of methyl chloride emitted from glasshouse-grown tropical plants and its implication for the global methyl chloride budget, Geophys. Res. Lett., 35(8), doi:10.1029/2007GL032736.

Saltzman E. S., Aydin M., De Bruyn W. J., King D. B. and Yvon-Lewis S. A. (2004), Methyl bromide in preindustrial air: Measurements from an Antarctic ice core, J. Geophys. Res.-Atmos., 109(D5), doi:10.1029/2003JD004157.

Sellevag S. R., Nyman G. and Nielsen C. J. (2006) Study of the carbon-13 and deuterium kinetic isotope effects in the $\mathrm{Cl}$ and $\mathrm{OH}$ reactions of $\mathrm{CH} 4$ and CH3Cl, J. Phys. Chem. A, 110(1), 141-152, doi:10.1021/jp0549778.

Shorter J., Kolb C., Crill P.M., Kerwin R., Talbot R., Hines M. and Harriss R. (1995) Rapid Degradation of Atmospheric Methyl-Bromide in Soils, Nature, 377(6551), 717-719, doi:10.1038/377717a0.

Shouakar-Stash O., S.K. Frape S.K., Drimmie R.J. (2005) Determination of bromine stable isotopes using continuous-flow isotope ratio mass spectrometry. Anal. Chem., 77, 4027.

Shouakar-Stash O., Alexeev S., Frape S., Alexeeva L., Drimmie R. (2007) Geochemistry and stable isotopic signatures, including chlorine and bromine isotopes, of the deep groundwaters of the Siberian Platform, Russia. Appl Geochem, 22, 589-605.Szatkowski L., Dybala-Defratyka A., Batarseh C., Blum J., Halicz L., Gelman, F. (2013) Bromine kinetic isotope effects: insight into Grignard reagent formation. New J. Chem., 37, 2241-2244.

Thornton B. F., Horst A., Carrizo D., Holmstrand H., Andersson P., Crill P. M. and Gustafsson O. (2013) A high-volume cryosampler and sample purification system for halogen isotope studies of methyl halides, J. Atmos. Oceanic Technol., doi: 10.1175/JTECH-D-12-00228.1 
Thompson A. E., Anderson R. S., Rudolph J. and Huang L. (2002) Stable carbon isotope signatures of background tropospheric chloromethane and CFC113, Biogeochemistry, 60(2), 191-211, doi:10.1023/A:1019820208377.

Varner R. K., Crill P. M. and Talbot R. W. (1999) Wetlands: a potentially significant source of atmospheric methyl bromide and methyl chloride, Geophys. Res. Lett., 26(16), 2433-2435, doi:10.1029/1999GL900587.

Van der Werf G. R., Randerson J. T., Giglio L., Collatz G. J., Kasibhatla P. S. and Arellano A. F. (2006) Interannual variability in global biomass burning emissions from 1997 to 2004, Atmos. Chem. Phys., 6, 3423-3441.

Warwick N. J., Pyle J. A. and Shallcross D. E. (2006) Global modelling of the atmospheric methyl bromide budget, J. Atmos. Chem., 54(2), 133-159, doi:10.1007/s10874-006-9020-3.

Wieser M. E., Holden N., Coplen T. B., Böhlke J. K., Berglund M., Brand W. A., De Bièvre P., Gröning M., Loss, R. D.; Meija, J.; et al. (2013) Atomic Weights of the Elements 2011 (IUPAC Technical Report). Pure Appl. Chem., 85, 10471078

Wishkerman A., Gebhardt S., McRoberts C. W., Hamilton J. T. G., Williams J. and Keppler F. (2008) Abiotic Methyl Bromide Formation from Vegetation, and Its Strong Dependence on Temperature, Environ. Sci. Technol., 42(18), 68376842, doi:10.1021/es800411j.

Yvon-Lewis S. A., Saltzman E. S. and Montzka S. A. (2009) Recent trends in atmospheric methyl bromide: analysis of post-Montreal Protocol variability, Atmos. Chem. Phys., 9(16), 5963-5974, doi:10.5194/acp-9-5963-2009.

Zafrilla B., Martínez-Espinosa R.M., Alonso M.A. and Bonete M.J. (2010) Biodiversity of Archaea and floral of two inland saltern ecosystems in the Alto Vinalopó Valley, Spain. Saline Systems 6(10), 1-12 


\title{
Electronic Annex for
}

\section{Stable bromine isotopic composition of methyl bromide released from plant matter}

\author{
Axel Horst, Henry Holmstrand, Per Andersson, Brett F. Thornton, Asher \\ Wishkerman, Frank Keppler, Örjan Gustafsson
}

Content:

Table EA-1: quantification of $\mathrm{CH} 3 \mathrm{Br}$ emissions (expressed as $\mathrm{Br}$ ) for the temperature series experiment

Fig. EA-1: emission of $\mathrm{Cl}$ and $\mathrm{Br}$ released as $\mathrm{CH}_{3} \mathrm{Cl}$ and $\mathrm{CH}_{3} \mathrm{Br}$ for the time series experiment 
Table EA-1: Bromine emission rates $\left(\mu \mathrm{gdw}^{-1} \mathrm{~h}^{-1} \mathrm{Br}\right)$ and the total emitted mass of bromine (emitted as $\mathrm{CH}_{3} \mathrm{Br}$ ) for selected incubation steps from the temperature series. The fraction remaining $(f)$ indicates the fraction of salt remaining in the plant matter after the emission of bromine in the form of $\mathrm{CH}_{3} \mathrm{Br}$.

\begin{tabular}{|c|c|c|c|c|c|c|c|}
\hline${ }^{\circ} \mathrm{C}$ & $\begin{array}{l}\text { pectin } \\
\mu \mathrm{gdw}^{-1} \mathrm{~h}^{-1} \mathrm{Br}\end{array}$ & $\mu \mathrm{g} B r$ tot. & $f$ & $\begin{array}{l}\text { Salicornia } \\
\mu \mathrm{g} \mathrm{gdw}^{-1} \mathrm{~h}^{-1} \mathrm{Br}\end{array}$ & $\mu \mathrm{g} \mathrm{Br}$ tot. & $f$ & $\begin{array}{l}\text { incubation } \\
\text { hours }\end{array}$ \\
\hline 30 & 0.003 & 1.7 & $>0.99$ & & & $>0.99$ & 504 \\
\hline 70 & 0.2 & 27.0 & $>0.99$ & 0.001 & 0.2 & $>0.99$ & 168 \\
\hline 110 & 3.4 & 3.4 & $>0.99$ & 0.1 & 0.1 & $>0.99$ & 1.0 \\
\hline 180 & 643.3 & 321.6 & 0.95 & 15.8 & 7.9 & 0.99 & 0.5 \\
\hline 300 & 18925.6 & 3785.1 & 0.53 & 262.2 & 52.4 & 0.89 & 0.2 \\
\hline
\end{tabular}



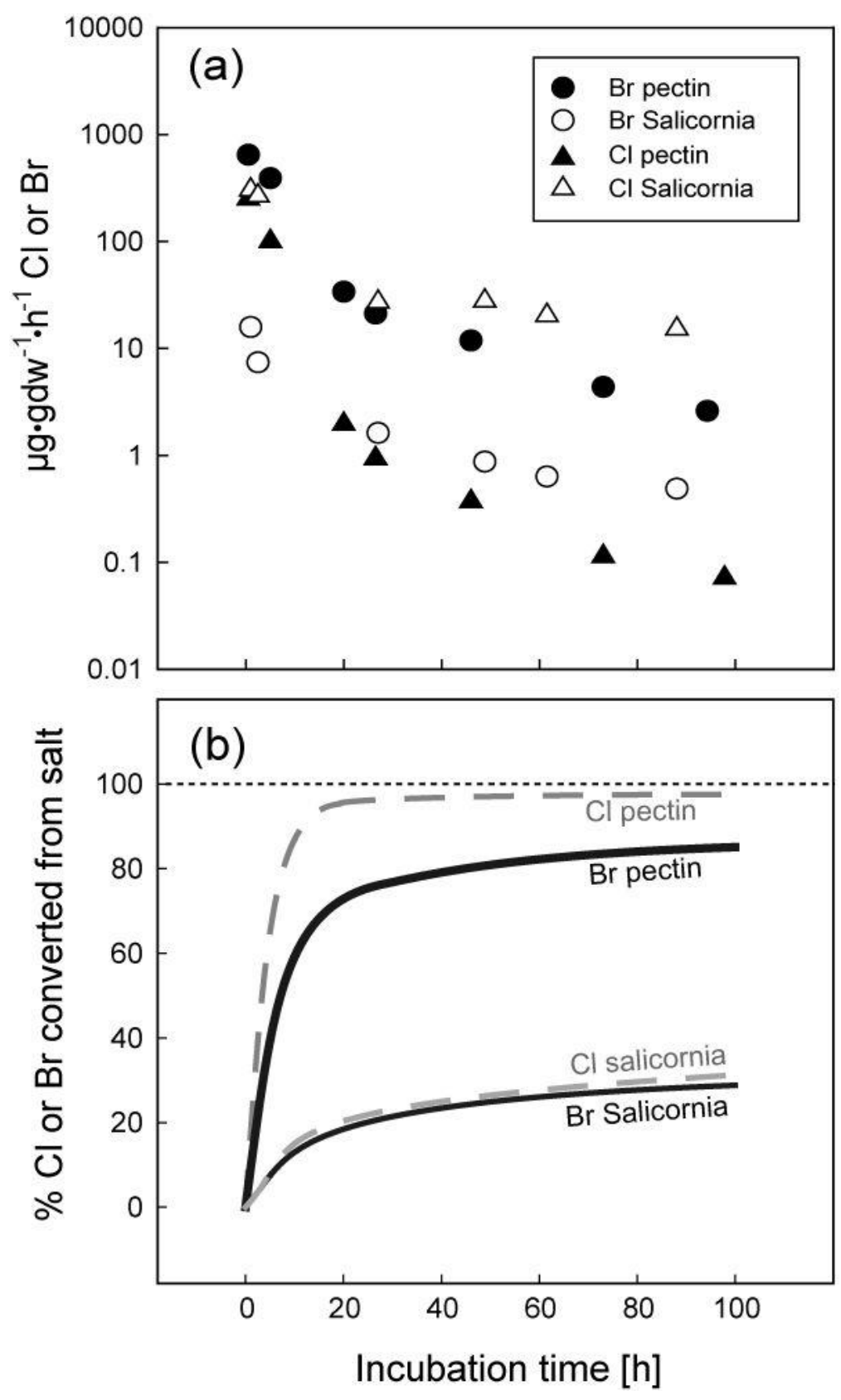

Fig. EA-1. (a) Rates of $\mathrm{Cl}$ and $\mathrm{Br}$ released as $\mathrm{CH}_{3} \mathrm{Cl}$ and $\mathrm{CH}_{3} \mathrm{Br}$ emissions from Salicornia fruticosa and fortified pectin for the individual samples $\left(180^{\circ} \mathrm{C}\right.$ experiments). (b) Cumulative amounts of $\mathrm{Br}$ and $\mathrm{Cl}$ released as $\mathrm{CH}_{3} \mathrm{Cl}$ and $\mathrm{CH}_{3} \mathrm{Br}$ from Salicornia and pectin (as \% converted from the salt). Amounts between the individual samples were interpolated. The dotted grey line marks complete conversion of $\mathrm{Cl} / \mathrm{Br}$ salt to $\mathrm{CH}_{3} \mathrm{Cl} / \mathrm{CH}_{3} \mathrm{Br}$. 